\title{
Богдан Калюсский
}

\section{ВОССТАНИЯ РАБОВ-МУСУЛЬМАН И КРИСТАЛЛИЗАЦИЯ ГРАЖДАНСКОГО ПЛЮРАЛИЗМА В БРАЗИЛИИ}

Бразилия является государством, периферийным к основному территориальному массиву исламского мира. Сложно дать объективные оценки численности или провести анализ демографической динамики мусульманской общины этой страны. Согласно последней переписи населения, проведённой Бразильским институтом географии и статистики, в 2010 г. здесь насчитывалось немногим более 35 тыс. мусульман [IBGE: Censo Demografico, 2012]. Данные официальной статистики в самом бразильском обществе оспариваются как морально устаревшие и не отражающие реальной конъюнктуры. Мусульманские организации заявляют о полутора миллионах адептов ислама в Бразилии, что, однако, нуждается в перепроверке. Тем не менее, даже безотносительно точных цифровых значений, можно принять за самоочевидный факт, что ислам на земле Бразилии присутствует в своей институциональной полноте; по подсчётам антрополога д-ра Лидисе Мейер Пинту Рибейру из Университета Сан-Паулу, на 2012 г. здесь функционировало 90 зарегистрированных исламских учреждений, 60 мечетей, 120 молитвенных комнат, служило полсотни представителей духовенства, египетских, марокканских и мозамбикских шейхов [Рибейру, 2012: 15].

Предмет нашего рассмотрения составляет эпизод в истории Бразилии, в котором исламский (и маврский, если понимать под «маврами» вообще чернокожих) фактор имел ключевое значение для становления не только и не столько локальной исламской общины, сколь бы интереса она ни была. В литературе обоснованно высказывается мнение о том, что восстания в Баия, которые и будут описаны в настоящей статье, по последствиям оказались много шире собственно бразильско-мусульманских корреляций. С ними связывается ускорение той коренной трансформации общественных институтов, которая дала привычный образ Бразилии с её этно-расовым, культурным и конфессиональным балансом. Череда событий, о которых пойдёт речь, носила протяженный во времени характер, начавшись в первой половине XIX в. и завершившись превращением Бразилии в государство прогрессивной - по меркам эпохи - социальной политики и гражданского многообразия. Ввиду значимости последствий т.н. «восстаний мале» или «восстаний Баия», позволительно утверждать, что перед нами наиболее важный след, который мусульмане оставили в борьбе юга Америки за гражданские свободы, упразднение рабовладельческих порядков и равноправие.

Будет нелишним упомянуть классификацию фаз закрепления ислама на землях Бразилии, которую предлагает социолог Веласкес Фильо Мендоса [Рибейру, 2013: 185]. Она отсчитывается с XVIII в., когда в провинцию (ныне - штат) Баия начался завоз исламизированных рабов-африканцев. Вторая фаза совпала с массовой иммиграцией в Бразилию выходцев из арабских стран, по большей части ливанцев и сирийцев в первой половине $\mathrm{XX}$ в. Третья, актуальная фаза приходится на конец прошлого столетия и связана с исламским прозелитизмом среди коренных бразильцев. Для наших целей необходимо остановиться на первом этапе имплантации ислама: появлении в Бразилии чернокожих рабов-мусульман, вехами их коллективной истории.

Хронологически более точным начало появления африканцев на сахарных плантациях Бразилии видится не в XVIII в., но в 1550-е годах [Симонсен, 1937: 196]. Впрочем, имеется указание на то, что рабы в небольшом числе впервые могли ступить на землю Бразилии ещё в 1516 г., когда капитану Сент-Винсенте было позволено запустить сахарный завод [Гуларт, 1950: 95]. Бесспорно, однако, то, что, начиная с 1549 г., ввоз африканцев на плантации Бразилии был поставлен на поток. Множество рабов из Анголы, Гвинеи-Бисау, Сенегамбии и Бенинской бухты, собирательно называемых бозале, в промежутке с XVI по XIX вв. были доставлены для труда в северо-восточные провинции Пернамбуко и Баия. В XVII в. чернокожие полностью заменили собой рабов-индейцев и в бразильских учётных документах позднейшей датировки под «рабским трудом» понимался труд исключительно африканцев.

Большинство из тех, кто к концу XVIII в. был задействован на плантациях, принадлежало к народностям хауса и йоруба. Как правило, они были пленниками, захваченными в ходе религиозных и межплеменных войн в районах Центрального Судана: Гурме, Боргу, Нупе, Борно и проч. [Реиш, 2003: 159] Вместе они составили гипотетическую вторую волну мусульманской эмиграции в Бразилию после появления там португальцев, при которых также предположительно имелось некое число африканских рабов. 
Государственное управление предпочитало выписывать негров различного этнического происхождения, опасаясь возникновения гомогенных агломераций, способных восстать против хозяев. Кроме того, португальцам было известно о серьёзных трениях между сохранявшими языческую веру в ориша народностями йоруба и par excellence мусульманами хауса.

Бразилия по одним оценкам приняла от 3-х до 4-х миллионов рабов из разных уголков Африки цифру, превышающую треть от всех невольников, когда-либо вывезенных с чёрного континента. Другие авторы утверждают, что с 1600 по 1800 гг. в страну прибыло 12 миллионов рабов из Африки [Калогераш, 1998: 302]. Дать сколько-нибудь усреднённые оценки масштабам рабовладельческого рынка Бразилии затруднительно. - Все дневники невольничьих судов, таможенные декларации, договоры купли-продажи рабов, владетельные записки, гражданские и церковные свидетельства были уничтожены по указу министра Барбосы от 14 декабря 1890 г. Не оспаривается лишь то, что в Бразилии возникла максимальная за всю историю рабовладельческой Америки концентрация африканских рабов-мусульман, доля которых среди чернокожего контингента была велика [Лавджой, 2007].

Будучи ревнителями католицизма, португальцы содействовали переходу африканцев в христианство римского обряда. Йоруба легче подвергались аккультурации, поскольку для воспроизводства их мифа требовалась жреческая корпорация, способная к осуществлению сложных церемоний, толкованию запутанной мифологии с пантеоном главных и младших божеств. В провинции Баия они были менее ассимилированы, зато активно воздействовали на формирование афро-бразильской религии, известной как кандомбле. Что касается крипто-мусульман, то против них (вернее угрозы их апостасии) вводились ограничительные меры. На открытое отправление исламского культа в Баия с 1594 г. распространялся запрет, в котором нашла отражение репрессивная судебно-инквизиторская практика Португалии, преследовавшая морисков и аналогичные группы в метрополии и колониях. Если прошедшего крещение африканского мусульманина застигали за отправлением исламских обрядов, мера наказания могла быть предельно суровой, вплоть до аутодафе. Статья 277 уголовного уложения Бразильской Империи (1830 г.) криминализировала всякое «оскорбление или издевательство над любым культом, основанном в Империи» [Уголовный кодекс Бразильской Империи, 2003], прописывая санкцию в виде штрафа или заключения под стражу сроком до полугода. Без излишней юридической казуистики под действие нормы закона подпадали случаи призыва к возвращению в ислам, адресованного номинальным выкрестам. Достаточно было доказанного обвинения в распространении среди группы, состоящей более чем из пятнадцати человек печатной, литографированной или рукописной периодики соответствующего содержания. Действие статьи охватывало также случаи выступлений с призывами к крамоле на публичных собраниях и в культовых местах христиан.

Понуждение к смене веры встречало закономерное противодействие со стороны как порабощенных исламских проповедников, так и лиц, просто обученных арабской грамоте. Познакомившись с культурой йоруба, португальцы начали обозначать мусульманских рабов - по большей части хауса - термином мале. Предположительно этот номинатив представляет собой искажённое произношение одного из слов на йоруба, хауса или арабском, по поводу его этимологии высказываются несколько несогласованных между собой мнений. Один извод трактует его как указание на образованного мусульманина, в чём прослеживается родство с малами языка хауса (которое в свою очередь восходит к арабскому му'аллим, «наставник») [Кеттани, 2016: 1-10]. Вторая точка зрения постулирует связь «мале» с названием одной из крупнейших государственностей в долине Нигера - средневековой Империей Мали [Рамуш, 1951: 317 ]. Третий подход принимает его как имале, т.е. закреплённый португальцами в речевом обиходе пейоратив: в языке язычников-йоруба им обозначался «ренегат, перешедший в мусульманство», нечто сопоставимое по семантике с «басурманином». Мы склоняемся к тому, что «мале» всё же восходило к презрительной кличке «имале» и отражало изначально неровные отношения между язычниками-йоруба и мусульманами-хауса. В таким случае, обозначение исламских духовных авторитетов словом с уничижительным для них значением следует рассматривать как дополнительный фактор, настраивающий мусульман против административных порядков.

В качестве ремарки укажем на то, что по своему общему культурному уровню, грамотности и кругозору мале, включая юных рабов, в подавляющем большинстве превосходили новых хозяев, малообразованных португальцев [Амаду, 1999]. Нина Родригеш отмечает, что интеллектуальный костяк вновь прибывших образовывали суданцы. В отличие от работяг-йоруба среди чёрных рабов хауса почитались за своеобразную «умственную аристократию» [Фрейре, 1980: 310]. Они же были социальным драйвером, вокруг которого возникали первые массовые движения в кварталах компактного проживания рабов. Португальцы признавали за образованными мале превосходство в знаниях и навыках, поэтому освобождали их от тяжёлого физического труда, перепоручая ведение торговых сделок или коммунальное обустройство городов и поселений. Богатея и процветая - иногда больше, чем их сеньоры - они осваивали целые сектора экономики, выкупали себя из рабства, получая минимальный объём гражданско-политической 
самостоятельности. Таким неграм выплачивалась регулярная заработная плата, они складывали особую категорию «оплачиваемых рабов», социальным союзам которых позже предстоит сыграть едва ли не ключевую роль в событиях 1835 г.

Рядовых верующих португальцы именовали муссуримим, что, по всей видимости, есть исковерканное арабское муслимин, «мусульмане». Среди них тоже имелись попытки саботажа навязываемого католичества, но не будучи знатоками собственной веры, они вольно или невольно давали старт синкретическим культам. Имеются указания на то, что, к примеру, в штате Алагоас, куда бежали после неудачи первых восстаний рабы-мусульмане, католические элементы причудливо смешивались с исламскими доктринами и ритуалами (положим, пост в месяц рамадан объединялся с праздником Святого Духа) [Дуарте, 1958: 41]. Некоторые чернокожие мусульмане в пику официозному бразильскому католицизму предпочитали для проформы обращаться в те или иные протестантские деноминации.

Отстаивая веру и опасаясь преследований, рабы нередко были вынуждены прибегать к практике такия. Более свойственная шиитскому исламу, она была принята африканскими суннитами в качестве вынужденной уловки по сокрытию истинных убеждений. Подобная мимикрия допускала формальный переход в католицизм с последующей латинизацией или заменой личных имён на христианские. Этническую базу крипто-мусульман по-прежнему составляли представители народностей хауса и йоруба (их здесь называли наги). К ним присоединялись мандинке и волоф, а также креолизированное цветное население. Имея на родине догматические различия, в неволе африканцы-мусульмане формировали новую сборную, устойчивую идентичность. К перешагиванию разночтений в интерпретации шариатских методологических и доктринальных частностей их подталкивал образ Другого как источника угрозы - белых колонистов, рабовладельцев-лузофонов.

Многие мале принимали крещение, продолжая организовывать тайные собрания, на которых преподавали Коран и обучали базовым исламским ритуалам. Что касается рабов, которым была дарована свобода или которые сами выкупили себя, то в их среде наблюдалась отчётливая тенденция к возвращению в ислам после индивидуального покаяния. В путевом дневнике, датированном 1866 г., имам Абд ар-Рахман аль-Багдади подтверждает вышесказанное следующей записью: «Все те, кто по праву достиг свободы, вспомнили религию своих предков, к которой они обратились после освобождения»1 ${ }^{\text {[Фарах, } 2009: 90] .}$ Автор пишет, что ради сохранения веры на чужбине свободные мусульмане создавали в сельской местности завуалированные молитвенные дома, школы и залы собраний (маджлис). Обучение в них вели владевшие арабским языком знатоки Корана. Члены общины изучали арабский, намереваясь использовать его в повседневном конспиративном общении, исламская религия выступала консолидирующим фактором. Культивация религиозного самосознания в среде этих афро-бразильцев продолжалась; пусть и в сильно редуцированном виде, но была сохранена и могла воспроизводиться их мусульманская самость.

Саботируя означенные нами ранее положения Уголовного кодекса, освобожденные рабы смелее проповедовали исламское вероучение в Сальвадоре. Для этого ими избирались такие места близ католических храмов и монастырей, как аллея Мата-Поркоса или Крузейру-ди-Сан-Франциско. В своих речах агитаторы обличали католическую мессу, не забывая порицать культ святых как неприемлемый для мусульман политеизм. Эти и ряд других немаловажных наблюдений приводит аль-Багдади приводит в книге «Восторг иностранца о делах дивных и прекрасных», в которой описал опыт посещения Бразилии в 1866-1869 гг. Насколько известно, он стал первым арабским имамом, прибывшим в Бразилию, автором единственной литературной фиксации арабского взгляда на Новый Свет в XIX в. и пассажиром первого корабля из Османской империи в бразильские земли. Там аль-Багдади оставался для обучения мусульман (предпочитавших, по его воспоминаниям, не откликаться на «мале») арабскому языку и Корану. Если верить иракскому имаму, за время его пребывания в Бразилии численность мусульман увеличилась с 5 тыс. до 19 тыс. человек, в основном за счет неофитов и реконвертитов (повторно принявших ислам).

Волнения мусульман превращались точкой наибольшего накала в их взаимоотношениях с белыми сеньорами. С разной интенсивностью они вспыхивали в Баия на протяжении почти тридцати лет, начиная с восстания 1807 г. Его организаторы предполагали захватить во время праздника тела и крови Христовых церковь в районе Назаре, установить власть над городом, затем перекинуть восстание на Пернамбуку и провозгласить Великое королевство хауса в Бразилии. Социальными предпосылками восстания стало увеличение доли освобожденных рабов. Так, согласно переписи населения, которая была проведена в Сальвадоре, административном центре провинции, к 1808 г. в одних только сельских приходах значилось свыше 104 тыс. свободных и освобожденных африканцев и мулатов. Рабов, чёрных и мулатов, насчитывалось примерно равновеликое количество - чуть более 93 тыс. [Реиш, 2003: 22]. При таком численном уравнивании свободных и невольных недовольство последних своей долей, аболици-

\footnotetext{
${ }^{1}$ Важный для изучения истории и социальной антропологии ислама в Бразилии текст написан в жанре рихла, или записок путешественника, его арабский оригинал хранится в Стамбульской библиотеке. На португальский он был переведен и снабжен пояснениями Паулу Даниэлем Фарахом.
} 
онистские лозунги, всплески недовольства представлялись социально детерминированными, а потому неизбежными.

Некоторые авторы прослеживают корни многочисленных восстаний мале в богословском разделении понятий хиджры и джихада [Шариф, 1998: 12-13]. В соответствии с таким прочтением первоначально бунтари выдвигали радикальные, но теоретически исполнимые требования к колониальной администрации, требуя возвращения в Африку. Ответной мерой на отказы португальцев становились бунты, их предводителями определяемые как борьба угнетённых, джихад аль-мустазафин. Изыскания Международного института исламо-африканских исследований Санкоре показывают нам, что лидеры восставших считали себя носителями освободительной миссии, оказавшимися на южноамериканском фронте борьбы с неверием. Её на их родном континенте, в Центральном и Западном Судане неустанно вёл основатель халифата Сокото, теолог-военачальник из народности фулани, крайне авторитетный для хауса Усман дан Фодио (1754-1817). В 1804 г., за несколько лет до первого из восстаний в Баия, он, строгий пурист, объявил священную войну племенам, которые смешивали исламские верования с анимистическими. В результате череды религиозно-политических войн, получивших название «джихадов фулани», часть захваченных в плен воинов с обеих сторон были проданы с невольничьих рынков в Бразилию.

Данное обстоятельство помогает глубже уяснить, почему предводителями афро-бразильских восстаний становились люди с военными компетенциями: стратеги, племенные лидеры и комбатанты, ранее приобретшие опыт сражений в Африке. Под их началом лишь в провинции Баия хауса поднимали знамя борьбы в 1807, 1809, 1814, 1815 и 1816 гг. С небольшим интервалом их повстанческая активность возобновлялась так же серийно в 1826, 1827, 1828 и 1830 гг. Нужно отметить, что активизация в 20-е годы XIX в. связана с оборотами, которые набрала массовая исламизация йоруба, и со свойственным неофитам радикализмом. В этот период йоруба отказываются от использования слова «мале» применительно к лидерам хауса, заменяя его на почтительное «алуфа», которым обозначался знаток Корана. Начиная с восстания 1826 г., на первый план выходят повстанцы-йоруба.

Кульминации бунтарская активность достигла в 1835 г. К этому времени в провинции накопилась критическая масса недовольных текущим положением вещей африканцев, уже достаточно сплочённых невзирая на их этническую, географическую, конфессиональную разнородность. Не обошлось и без некоторой каузальной связи: в 1831 г., стремясь обойтись требования международного договора о трансатлантической работорговле, а равно избежать декларирования живой силы и сопряжённых с этим налогов, плантаторы запросили увеличенную партию рабов, которую из колониального Сан-Томе направили в Баия. Эта «свежая кровь» не была рождена в Бразилии, а значит, в отличие от креолов являлась носительницей более свободного духа.

Образовав значительную концентрацию в одном месте, новоприбывшие африканцы общались между собой на йоруба, хауса и арабском. Другими религиозными маркерами восставших являлась типовая одежда, распространенность амулетов с фрагментами из Корана, обилие исполненных по-арабски агитационных листовок и выбор времени для восстаний, нарочито совпадавший с памятными или значимыми для мусульман датами. Факт объединения вокруг знания арабского в качестве тайного коммуникативного кода и почитание Корана, несмотря на присвоенные им христианские имена имеет центральное значение в оценке восстания как вдохновленного служителями исламского культа [Да Круз Бриту, 2016 ].

Детально изучивший события 1835 г. Жоао Жозе Реиш отмечает примечательный факт, когда говорит о том, что организаторы восстания не выступали на волне сколько-нибудь стихийных настроений. Они руководствовались и внедряли в умы своих товарищей политическую программу, финальной точкой которой объявлялся захват административной и религиозной власти с провозглашением в Баия не просто государства чернокожих (как это имело место в первых восстаниях), но исламской державы [Реиш, 2003, 72-73]. Задача не кажется чересчур амбициозной, если принимать во внимание, что мусульмане, чёрные рабы и вольноотпущенники, были представлены в Сальвадоре в таком количестве, что путешественники отзывались о нём как об «африканской столице». Плюс к тому в 1835 г. стёрлась либо притупилась имевшаяся в начале столетия межконфессиональная враждебность йоруба и хауса. По подсчётам Реиша люди с африканским происхождением (включая мулатов и метисов) составляли 78\% провинциалов, из них $63 \%$ были рождены в различных уголках Африки, а значит, еще не утратили связи с родиной.

Абсолютное большинство афро-мусульман сперва по не зависящей от них воли рабовладельцев-плантаторов, а затем вполне осознанно стекалось в Баия, далее устремляясь в Сальвадор [Бастиде, 1989]. В нём к 1835 г. мусульмане составляли треть населения, из которых 21\% обладал статусом свободных. Закрепляясь в городе, эти люди могли обсуждать текущие политические события в ассоциациях «оплачиваемых рабов», планировать на собраниях детали грядущих выступлений. Их исламская солидарность наряду с чувством чужеродности христианской культуре Бразилии послужили цементом, который объединял это смешанное в расовом и языковом смыслах сообщество, прошивая его насквозь от простого батрака до принца [Оливейра, 1997]. Кроме прочего, рабов-мусульман уязвляло то обстоятельство, что 
даже выкупая свободу, они до конца жизни были ущемлены в политических правах по сравнению не только с белым, но и с автохтонным индейским населением. Другими словами, бунтарские настроения подогревало неприятие африканцами положения «людей третьего сорта».

Это проясняет, почему требования организационного костяка восстания сочетали в себе антирабовладельческий пафос с запросом на юридическое равенство представителей трёх рас. Среди поддержавших преимущественно мусульманское движение 1835-го года были фетишисты и анимисты, которые руководствовались неприятием мира сеньоров, бунтуя от отчаянности своего бесправия. Отдавая должное чернокожему населению других вероисповеданий, мусульманские идеологи инсургентов предусматривали в случае победы режим большей толерантности к афро-бразильским культам, чем позволяли католики-португальцы (как мы помним, в некоторых очагах социальных брожений чернокожих, особенно в Пернамбуку, исламские культы могли сочетаться с магией, геомантией и нумерологией). В таком сплочении вокруг общих задач чётко просматривается шаг в сторону от межплеменных и межрелигиозных распрей, которые омрачали отношения хауса и йоруба на родине. В то же время в литературе можно встретить попытки осмысления ${ }^{2}$ вывода Этьена Игнасе о том, что движение носило не только «политический и социальный характер; оно не было усилием по достижению свободы; напротив, оно имеет примечательный религиозный характер: одним словом, это была священная война» мусульман [Игнасе, 1970: 11].

Этим объясняется любопытный штрих историка Сержиу Ферретти: восстания мале на протяжении первой половины XIX в. преднамеренно планировались так, чтобы их ударная фаза выпадала на важный для католиков святой день вроде Рождества [Феретти, 1988]. Когда улицы Сальвадора пустели, а жандармерия и солдаты были отвлечены на мессу, мусульмане с тактическим преимуществом для себя могли добывать оружие и боеприпасы в небольших гарнизонах, освобождать единоверцев из тюрем. Как уже было сказано, первые восставшие стремились захватить корабли, чтобы вернуться в Африку. Тем удивительнее то обстоятельство, что самое значительное выступление против властей, произошедшее в 1835 г., мале уже не ассоциировали с мечтой о «великом африканском исходе». Произошедшая с людьми метаморфоза показательна, поскольку, смирившись с Бразилией как вынужденным пристанищем, они совершили рывок в формировании уникальной афро-бразильской, уже почвеннической исламской идентичности.

Пиковое событие 1835 г. случилось в ночь на 24 января, когда подходил к концу священный месяц рамадан. В Сальвадоре вспыхнули беспорядки, которым суждено было стать крупнейшим городским восстанием рабов не только Бразилии, но и во всём Новом Свете. Выпадение его на одно из последних чисел рамадана, когда мусульмане ожидают наступления ляйлят аль-кадр, «ночи предопределения» и прощения грехов, послужило мобилизующим фактором достаточной силы. Возможно, бунтовщики видели в нём некую гарантию мученической смерти и залог их персональной сальвации. Неслучайный выбор сакральной ночи подтверждается также тем, что в нагрудных коробочках-мандинге, где восставшие хранили фрагменты Корана, полицейскими были обнаружены свитки 92-й суры «Аль-Ляйль» («Ночь предопределения»).

Само восстание продлилось меньше суток, оно было подавлено утром 25 января армией совместно с вооружённым гражданским ополчением. Обширной базы источников, посвященных этому архиважному эпизоду истории Баия, до нас не дошло, однако следователям полиции стала доступна конспиративная переписка лидеров мале, которую те вели на арабском языке. Она свидетельствует о том, что выступление рабов загодя планировалось с таким умыслом, чтобы совпасть не только с рамаданом, но и с католическим фестивалем в почитаемой местными католиками Церкви Господа нашего в Бонфине. В подобном вызове, в его символической декларативности читается реакция, копимая чернокожими и креолизированными мусульманами за десятилетия посягательства на их веру.

Планировалось, что повстанцы захватят городскую ратушу, сея панику, и устроят поджоги в разных частях города, дабы дезориентировать власти и армию. Синхронно с ударной группой другая часть повстанцев во главе с мусульманскими лидерами Мануэлем Калафате, Паи Инасио и неким Априжиу [Рохлофф ди Матуш, 2009] должна будет осуществить акцию освобождения из муниципальной тюрьмы Ахумы и Пасифико Биляля Ликутано, уважаемых старцев и вдохновителей мале. На примере двоих из упомянутых лиц мы встречаем образец того, как рабы присовокупляли к своим латинизированным именам или прозвищам аутентичные имена.

По всему Сальвадору группы восставших, численность которых по расчётам учёных колебалась от шестисот до полутора тысяч человек, противостояли полицейским силам и Национальной гвардии.

${ }^{2}$ CM. Mello Leal P. Leitura, Encantamento e Rebelião o Islã Negro no Brasil Seculo XIX. Niteroi: Universidade Federal Fluminense, 2009; Dos Santos Gomes R. A Erudição Islâmica na Bahia do Século XIX: O Islã Como Fundo Ideológico do Movimento Malê. Tempos Academicos. Revista do Curso de Histório, n. 7, 2009 
Кроме прочего, повстанцами были истреблены африканцы и креолы, которые не выказали поддержки повстанцам. Несколько часов длились столкновения между вооружёнными мачете и ружьями мале, которых отличали белые рубахи, чётки-тэссуба (внешне отличные от католического розария формой и размером), кожаные мешочки с рукописями сур на шеях, и кавалеристами района Агуа-де-Менинуш. На усиление кавалерии был брошен офицерский корпус, к которым присоединились солдаты соседних гарнизонов. Поддержку правительственным войскам оказывали вооружённые гражданские лица, встревоженные подъёмом «чёрных якобинцев», как впоследствии окрестит мале бразильская пресса. Подобные аллюзии с французскими революционерами могут быть истолкованы как знаки реального опасения зажиточных латифундистов, внушенные социальными лозунгами восставших.

Подавление восстания, спланированного заранее, но плохо и неумело режиссированного, обернулось репрессиями и ужесточением внутренней реакции имперских властей. По свидетельствам очевидцев, аресту подвергались как непосредственно причастные к восстанию, так и те рабы, которым не повезло лишь иметь при себе во время полицейских рейдов амулеты-мандинге или быть облачёнными в белые туники. Ужесточился надзор за мусульманами, вместо чаемых послаблений религиозной политики на какое-то время набрало силу насильственное крещение в католицизм. Победители отличились показательными наказаниями, обрекая рабов на смертные казни и каторжные ссылки. Тем не менее, многим удавалось избежать расправы, и люди укрывались в Рио-де-Жанейро. Туда же и в Рио-Гранде ду Сул их владельцам было возвращено некоторое количества сбежавших, а позже арестованных рабов (нет библиографических подтверждений, что они входили в какую-нибудь организованную исламскую ячейку). Стараясь не выдавать сотоварищей, зачинщики и командиры восставших притворялись безграмотными, отказывались переводить комиссии инквизиторов содержание записанных по-арабски дощечек и табличек. Благодаря этому манёвру удалось скрыть целый ряд имён предводителей, равно как масштабы вовлечённых народных масс.

Обращает на себя внимание такое последствие этого восстания, как высылка вольноотпущенников обратно в Африку. 30 апреля 1835 г. Законодательное собрание провинции Баия возложило на Государственное казначейство депортацию из страны лиц обоего пола, кто активно содействовал восставшим. Приходится констатировать, что пусть не мытьём, так катанием желавшие некогда репатриации мусульмане смогли покинуть заокеанскую чужбину и вернуться на свою прародину. Бразильское общество, представленное, в первую очередь, белыми грандами, политиками и крупными латифундистами, сделало далеко идущие выводы из последнего и крупнейшего восстания мале: сохранение рабовладельческого строя чем дальше, тем больше превращается в угрозу общему социальному порядку и спокойствию [Да Круз Бриту, 2009].

Неоспоримо значение для судеб афроамериканцев в целом, по обе стороны Америки, той черты, которую подвёл под бунтами чернокожих новый правитель Бразилии. Взошедший в 1831 г. на престол император Педру II (1825-1890) оставил по себе память как о человеке незлобивого нрава и либеральных увлечений. Рассмотрев опасный потенциал чёрных волнений, молодой император осознал, что рабовладельческая система изжила себя. Император относительно рано сделался приверженцем аболиционистских взглядов и ещё в первые декады своего правления имел виды на полное упразднение рабовладения. По некоторым причинам в начале его правления столь прогрессивное намерение сталкивалось с нежеланием вступать в конфликт с нобилями-рабовладельцами. Сверх того, государь испытывал давление как внутри страны, так и извне. В Бразилии ширилось республиканское движение, которое параллельно и с низов добивалось отмены невольничьего труда. Уровнем выше зрел заговор офицеров-либералов. В довесок отменившая рабство ещё в 1809 г. Британия не желала мириться с последней рабовладельческой державой в Западном полушарии.

В итоге, в 1850 г. правительство Бразилии ввело окончательный запрет на завоз рабов из Африки и выслало из страны португальских работорговцев. До Национальной гвардии, военно-морского флота и провинциальных властей было доведено распоряжение пресекать доступ кораблей с африканскими рабами в порты Бразилии. Наконец, 13 мая 1888 г. с принятием «Золотой буллы» страна официально отказалась от практики рабовладения. Следующим годом, в 1889-м, Бразилию провозгласили республикой, а любые гонения и лимитации по религиозному признаку были отменены. Всего через полвека была принята Конституция Бразилии 1949 г., которая закрепляла право религиозных сообществ на равноправное существование. По времени эта законодательная либерализация совпадёт с массовым притоком в Бразилию после Второй мировой войны иммигрантов-арабов из Сирии и Ливана. С их появлением упомянутый нами в начале Мендоса связывает вторую фазу утверждения ислама в бразильском обществе. Очевидно, что режим благоприятствования, распространившийся на арабских переселенцев, христиан и мусульман, не возник бы, не предшествуй ему многочисленные восстания мале.

В заключение скажем, что третья фаза имплементации ислама по Мендосе, а именно «неофитский бум» рубежа XX-XXI вв. в столь пёстром обществе, как бразильское, в немалой степени продиктован 
интересом афро-бразильцев и креолов к своим мусульманским корням. - Процесс, по ряду характеристик почти тождественный умонастроениям билалиане, как предпочитают называть себя новообращённые афроамериканцы в США. Типологически они представляют собой таких же потомков рабов, как и многие современные афро-бразильцы, которых в Новое время вывезли из мусульманских регионов Африки, крестили в Северной Америке и тем самым искусственно оторвали от корневой идентичности.

Дата, которой ознаменовался конец рабовладельческой эпохи Бразилии, в последующем стала красной в национальном календаре. По сей день мультирасовое, этнически разнообразное и религиозно неоднородное население этой огромной страны к востоку от Амазонки официально отмечает 13 мая Dia do Mulato - День мулата.

\section{Библиография:}

Amado J. (1999). Bahía de Todos os Santos. Madrid: Editoria Losada.

Bastide R. (1989). As Religiões Africanas no Brasil. Contribuição a uma Sociologia das Interpenetrações de Civilizações, n. 3. São Paulo: Livraria Pioneira Editora.

Calógeras J.P. (1998). A Política Exterior do Império. Vol. 1. Brasilia: Senado Federal.

Codigo Criminal do Imperio do Brazil. (2003). Coleção História do Direito Brasileiro. Direito Penal. Vol 1. Brasília: Senado Federal, Conselho Editorial.

Da Cruz Brito L. (2009). A Legalidade Como Estratégia: Africanos que Questionaram a Repressão das Leis Baianas na Primeira Metade do Século XIX. História Social, n. 16.

Da Cruz Brito L. (2016). Temores da África: Segurança, Legislação e População Africana na Bahia Oitocentista. Salvador: Editora da Universidade Federal da Bahia.

Duarte A. (1958). Negros Muçulmanos nas Alagoas: os Malês. Maceió: Caetés.

Farah P.D. (2009). Deleite do Estrangeiro em Tudo o que é Espantoso e Maravilhoso: Estudo de um Relato de Viagem Bagdadi. Rio de Janeiro: Fundação Biblioteca Nacional.

Ferretti S.F. (1988). Revoltas de Escravos na Bahia em Início do Século XIX. V. 4 (1). Saõ Luis: Caderno de Pesquisa. Freyre G. (1980). Casa-Grande e Senzala. Rio de Janeiro: Jose Olympio.

Goulart M. (1950). Escravidão Africana no Brasil. Das Origens à Extinção do Tráfico. São Paulo: Livraria Martins Editora.

Ignace E. (1970). A Revolta dos Malês. Afro-Asia, n. 10.

Instituto Brasileiro de Geografia e Estatistica: Censo Demografico 2010. Características Gerais da População, Religião e Pessoas com Deficiência. (2012). Rio de Janeiro, Brasil.

Kettani M. (2016). Bahia Muslim Slaves Rebellion: Rebellion of the Males, Brazil 1835. Cham: Springer International Publishing.

Lovejoy P.E. (2007). Muslim Encounters with Slavery in Brazil. Markus Wiener Publishing.

Oliveira M.I.C. (1997). La Grande Tente Nagô: Rapprochements Ethniques Chez les Africains de Bahia au XIX Siécle. Toronto.

Ramos A. (1951). Introdução à Antropologia Brasileira. Vol 1. Rio de Janeiro: Livraria Editora Casa do Estudante do Brasil.

Reis J.J. (2003). Rebelião Escrava no Brasil: a História do Levante dos Malês em 1835. São Paulo: Companhia das Letras.

Ribeiro L.P.M. (2012). A Implantação e o Crescimento do Islã no Brasil. Estudos de Religião. Vol. 26 , n. 43.

Ribeiro L.P.M. (2013). Yorubás e Malês: Conflito e Aliança no Brasil Escravocrata. Revista Lusófona de Ciência das Religiões. Vol. X, nn. 18-19.

Rohloff de Mattos I. (2009). Periodo Regencial Brasileiro. Grupo Escolar, Novembro 2.

Shareef M. (1998). The Islamic Slave Revolts of Bahia, Brazil. A Continuity of the $19^{\text {th }}$ Century Jihad Movements of Western Sudan. Pittsburgh: Institute of Islamic-African Studies International Sankore.

Simonsen R.C. (1937). História Econômica do Brasil 1500-1820. Série Brasiliana. Vol. 100. São Paulo: Companhia Editora Nacional.

\section{Kaliusskyi Bohdan}

\section{Rises of Muslim Slaves and the Crystallization of Civil Pluralism in Brazil}

The article considers a series of revolts and rebel movements of black slaves in Brazil during the first third of the $19^{\text {th }}$ century. The role of the Muslim community in the abolitionist processes of the largest South American state is highlighted. The author explores the process of formation of a multi-ethnic and multi-religious civil society in Brazil as a result of the revolutionary activity of enslaved African immigrants. A panoramic view of the search by the black population for new dimensions of identity and cultural genealogy of Afro-Brazilian religious practices is given. 


\section{Калюсский Богдан Аркадьевич}

Восстания рабов-мусульман и кристаллизация гражданского плюрализма в Бразилии

В статье рассмотрена серия бунтов и повстанческих движений чернокожих рабов в Бразилии на протяжении первой трети ХІХ века. Освещчается роль мусульманской общины в аболиционистских процессах крупнейшего южноамериканского государства. Автор исследует процесс становления полиэтнического и многоконфессионального гражданского общества Бразилии как результата револющионной активности порабощённых выходиев из Африки. Даётся панорамное представление о поисках чёрным населением новых измерений идентичности и культурной генеалогии афро-бразильских религиозных практик.

Калюсский Богдан Аркадьевич, Университет Ататюрка, Эрзурум, Турция; Украинский цฺентр исламоведения, Острожская академия, Украина.

Kaliusskyi Bohdan, Ataturk University, Erzurum, Turkey; Ukrainian Center of Islamic Studies of Ostroh Academy, Ukraine. 